\title{
Model Pendugaan Total Digestible Nutrient (TDN) pada Hijauan Pakan Tropis Menggunakan Komposisi Nutrien
}

\author{
A. S. Indah*, I. G. Permana, Despal \\ Departemen Ilmu Nutrisi dan Teknologi Pakan, Institut Pertanian Bogor, Bogor, Indonesia 16680
}

\begin{abstract}
ABSTRAK
Penelitian ini bertujuan untuk mengetahui hubungan antara total digestible nutrient (TDN) dengan komposisi nutrien hijauan (rumput dan legum) dan untuk menentukan prediksi persamaan TDN yang menunjukkan kualitas hijauan pakan tropis. Komposisi nutrien berasal dari data hasil penelitian yang telah dipublikasikan yang terdiri dari 52 hijauan (29 rumput (R) dan 23 legum (L)) meliputi kadar abu, protein kasar (PK), lemak kasar (LK), serat kasar (SK), bahan ekstrak tanpa nitrogen (BETN), neutral detergent fiber (NDF), acid detergent fiber (ADF), hemiselulosa, selulosa dan TDN (\%BK) digunakan dalam penelitian ini. Data yang diperoleh dianalisis dengan Korelasi Pearson dan regresi linier berganda untuk menentukan model pendugaan TDN. Model dengan koefisien determinasi dan probabilitas paling tinggi akan divalidasi dengan menggunakan mean absolute deviation (MAD), root mean square error (RMSE), mean absolute percentage error (MAPE). Hasil penelitian menunjukkan bahwa komposisi nutrien dapat digunakan untuk menentukan TDN pada hijauan tropis yaitu pada rumput dan legum. Hal tersebut ditunjukkan oleh nilai MAD, RMSE dan MAPE yang lebih rendah dibandingkan dengan rumus TDN lain. Model pendugaan TDN yang diperoleh yaitu $\mathrm{TDN}_{\mathrm{R}+\mathrm{L}}=49,866-3,488 \mathrm{Abu}+0,112 \mathrm{Abu} * \mathrm{PK}+0,056 \mathrm{Abu} * \mathrm{BETN}$; $\mathrm{TDN}_{\mathrm{R}}=49,875$ $+0,031$ Abu*PK; dan TDN $\mathrm{L}=15,212+5,084 \mathrm{LK}+0,070$ Abu*BETN. Berdasarkan hasil penelitian, maka dapat disimpulkan bahwa model pendugaan TDN dapat diestimasi secara akurat dari komposisi nutrien sehingga dapat digunakan untuk merepresentasikan TDN berdasarkan basis data hijauan tropis. Model pendugaan TDN yang dapat digunakan yaitu TDN $\mathrm{T}_{\mathrm{R}} \mathrm{L}$ dan TDNL.
\end{abstract}

Kata kunci: Hijauan tropis, Legum, Model pendugaan TDN, Rumput

\section{Determination Total Digestible Nutrient (TDN) of Tropical Fotage Using Nutrient Composition}

\begin{abstract}
This study aims to investigate the relationship between total digestible nutrient (TDN) with nutrient composition in tropical forage (grass and legume) and determine the TDN prediction equation for showing the quality of tropical forage. The nutrient composition data were obtained from published research results consist of 52 forages $(29$ grasses $(R)$ and 23 legumes $(L))$ including of ash, crude protein $(C P)$, ether extract $(E E)$, crude fiber $(C F)$, nitrogen- free extract (NFE), neutral detergent fiber $(N D F)$, acid detergent fiber $(A D F)$, hemicellulose, cellulose, and TDN $(\% D M)$. Pearson Correlation and multiple linear regression analyses were used to measure TDN estimated models. The model with the highest coefficient of determination and probability will be validated using mean absolute deviation (MAD), root mean square error (RMSE), mean absolute percentage error (MAPE). The results showed that nutrient composition can be used to determine TDN in tropical forages, namely grass and legumes, this is indicated by MAD, RMSE and MAPE values which are lower than the other TDN formula. Prediction equation TDN in tropical forage were $T D N_{R+L}=49,866-3,488$ Ash + 0,112 Ash *CP + 0,056 Ash $* N F E ; T D N_{R}=49,875+$ $0,031 \mathrm{Ash} * C P$; and $T D N_{L}=15,212+5,084 \mathrm{EE}+0,070 \mathrm{Ash} * N F E$. It concluded the equation TDN estimation model can accurately be estimated from nutrient composition so that it can be used to represent TDN based on a tropical forage database. $T D N$ estimation models that can be used are $T D N_{R+L}$ and $T D N_{L}$.
\end{abstract}

Keywords: Grass, Legume, TDN estimation model, Tropical forage

\section{PENDAHULUAN}

Hijauan merupakan sumber pakan utama dengan $>70 \%$ ransum ternak ruminansia terdiri dari pakan hijauan, untuk itu diperlukan upaya penyediaan hijauan makanan ternak yang cukup baik dalam kuantitas maupun kualitas dan berkesinambungan (Farizaldi, 2011). Pakan hijauan dapat diberikan dengan kombinasi rumput dan legum dibutuhkan untuk saling melengkapi unsur nutrien yang diperlukan oleh ternak (Koten et al., 2014). Selain itu penggunaan hijauan umumnya dapat mengurangi biaya pakan (Ginting, 2011). Kinerja ternak dipengaruhi oleh kualitas hijauan

*Penulis Korespondensi: Andi Sukma Indah Alamat: J1. Agatis Kampus Kampus IPB Dramaga, Bogor 16680 Email: andisukmaindah@gmail.com yang ditentukan oleh komposisi kimia dari hijauan tersebut. Pengetahuan mengenai komposisi kimia dari hijauan yang berbeda dapat memungkinkan formulasi ransum dengan keseimbangan nutrien sesuai dengan kebutuhan ternak. Komposisi kimia menunjukkan jumlah nutrien (terutama energi dan protein kasar) yang tersedia dan dapat dicerna (Cleland et al., 2018).

Faktor lingkungan dan manajemen pemeliharaan memiliki pengaruh yang besar terhadap perbedaan kualitas hijauan. Suhu dan kelembaban adalah dua variabel lingkungan yang sangat mempengaruhi kualitas hijauan selama pertumbuhan tanaman (Seglar dan Shaver, 2014). Kandungan serat dan protein hijauan tropis berturut-turut lebih tinggi dan lebih rendah dibandingkan hijauan subtropis (Archimede $e t$ al., 2018). Hal inilah yang menyebabkan adanya perbedaan kualitas hijauan subtropis dengan hijauan 
pakan di daerah tropis termasuk di Indonesia. Selain itu, terdapat pengaruh pemilihan hijauan pakan dan tingkat kematangan pada saat panen dan waktu layu untuk mencapai kandungan bahan kering yang tepat.

Formulasi ransum untuk ternak ruminansia dibuat berdasarkan total digestible nutrient (TDN) dan protein kasar (Rosendo et al., 2013). Pemanfaatan TDN dan protein tersebut sangat berpengaruh terhadap produktivitas ternak (Nugroho et al., 2013). Kelemahan TDN adalah tidak memperhitungkan energi secara rinci mengenai hilangnya zat-zat nutrisi yang dibakar saat metabolisme dan energi panas yang timbul saat mengkonsumsi pakan (Ferrel dan Oltjen 2008). Akan tetapi, Indonesia masih menggunakan TDN sebagai satuan energi pakan ternak ruminansia. TDN dari berbagai pakan yang diperoleh dari pendugaan komposisi ki mianya dinilai kurang tepat dikarenakan belum ada penelitian yang memvalidasi hubungan antara pendugaan TDN dengan pengukuran TDN di negara ini (Jayanegara et al., 2017). Hal tersebut mendasari perlunya validasi partisi energi. Rumus dalam penelitian Sutardi (1980), Hartadi et al. (1980), Wardeh (1981) dan Moran (2005) merupakan rumus pendugaan yang banyak digunakan. Akan tetapi, estimasi TDN diduga dari komposisi kimia pakan yang mengacu pada rumus pendugaan hijauan non tropis. Pendugaan TDN dapat diperoleh melalui komposisi kimia pakan melalui tabulasi pengukuran TDN secara in vivo (Detmann et al., 2008) dengan kualitas hijauan tropis. Oleh sebab itu, perlu kajian lebih lanjut tentang

Tabel 1. Deskripsi komposisi nutrien dan TDN rumput + legum $(n=52)$, rumput $(n=29)$ dan legum $(n=23)$

\begin{tabular}{|c|c|c|c|c|c|c|c|c|c|}
\hline \multirow{2}{*}{$\begin{array}{l}\text { Komposisi } \\
\text { Nutrien (\%BK) }\end{array}$} & \multicolumn{3}{|c|}{ Rumput + Legum } & \multicolumn{3}{|c|}{ Rumput } & \multicolumn{3}{|c|}{ Legum } \\
\hline & Rataan & Min & Mak & Rataan & Min & Mak & Rataan & Min & Mak \\
\hline$\overline{A b u}$ & $6,56 \pm 4,53$ & 1,52 & 18,04 & $5,39 \pm 5,64$ & 1,52 & 18,04 & $8,04 \pm 1,72$ & 4,80 & 11,72 \\
\hline PK & $12,79 \pm 5,91$ & 3,33 & 26,71 & $8,93 \pm 3,85$ & 3,33 & 16,58 & $17,66 \pm 4,22$ & 11,77 & 26,71 \\
\hline LK & $2,56 \pm 1,00$ & 0,95 & 05,62 & $1,88 \pm 0,36$ & 0,95 & 2,79 & $3,40=$ & 2,00 & 5,62 \\
\hline SK & $28,21 \pm 6,01$ & 15,32 & 38,42 & $30,29 \pm 3,99$ & 22,23 & 38,42 & $26,27 \pm 7,35$ & 15,32 & 37,10 \\
\hline BETN & $46,19 \pm 4,73$ & 36,32 & 59 & $47,42 \pm 4$ & 40,12 & 59 & 44,63 & 36,32 & 54,48 \\
\hline NDF & $60,08 \pm 16,43$ & 30,49 & 92 & $72,33 \pm 7,85$ & 46,18 & 92 & $44,63 \pm 10,01$ & 30,49 & 59,34 \\
\hline $\mathrm{ADF}$ & $36,13 \pm 8,56$ & 17,32 & 52,76 & $40,59 \pm 6,19$ & 29,24 & 52,76 & $30,52 \pm 7,88$ & 17,32 & 43,45 \\
\hline Hemiselulosa & $23,94 \pm 10,28$ & 8,73 & 45,99 & $31,74 \pm 5,77$ & 15,02 & 45,99 & $14,11 \pm 4,60$ & 8,73 & 30,09 \\
\hline Selulosa & $25,46 \pm 7,45$ & 9,71 & 39,24 & $29,38 \pm 5,65$ & 18,34 & 39,24 & $20,51 \pm 6,49$ & 9,71 & 32,48 \\
\hline TDN & $54,23 \pm 7,62$ & 36,98 & 72,88 & $51,71 \pm 6,35$ & 36,98 & 59,12 & $57,41 \pm 8,02$ & 39,67 & 72,88 \\
\hline
\end{tabular}

Keteragan: $\mathrm{PK}=$ protein kasar; LK = lemak kasar; SK = serat kasar; BETN = bahan ekstrak tanpa nitrogen; NDF = neutral detergent fiber; $\mathrm{ADF}=$ acid detergent fiber $; \mathrm{TDN}=$ total digestible nutrient

Tabel 2. Literatur pendugaan TDN

\begin{tabular}{|c|c|c|}
\hline Sumber & Ket & Rumus \\
\hline \multirow[t]{4}{*}{ Sutardi (1980) } & $\mathrm{SK}<18, \mathrm{PK}<20$ & $\mathrm{TDN}=2,79+1,17 \mathrm{PK}+1,74 \mathrm{LK}-0,295 \mathrm{SK}+0,81 \mathrm{BETN}$ \\
\hline & $\mathrm{SK}<18, \mathrm{PK}>20$ & $\mathrm{TDN}=25,6+0,53 \mathrm{PK}+1,7 \mathrm{LK}-0,474 \mathrm{SK}+0,732 \mathrm{BETN}$ \\
\hline & $\mathrm{SK}>18, \mathrm{PK}<20$ & $\mathrm{TDN}=70,6+0,259 \mathrm{PK}+1,01 \mathrm{LK}-0,76 \mathrm{SK}+0,091 \mathrm{BETN}$ \\
\hline & $\mathrm{SK}>18, \mathrm{PK}>20$ & $\mathrm{TDN}=3,17+0,64 \mathrm{PK}+2,08 \mathrm{LK}-0,0675 \mathrm{SK}+0,94 \mathrm{BETN}$ \\
\hline \multirow[t]{5}{*}{ Hartadi et al. (1980) } & Kelas 1 & $\begin{array}{l}\mathrm{TDN}=92.464-3,338 \mathrm{SK}-6,945 \mathrm{LK}-0,762 \mathrm{BETN}+1,115 \mathrm{PK}+0,031 \mathrm{SK} \\
\mathrm{SK}-0,133 \mathrm{LK}^{2}+0,036 \mathrm{SK} \mathrm{BETN}+0,207 \mathrm{LK} \mathrm{BETN}+0,100 \mathrm{LK} \mathrm{PK}-0,022 \\
\mathrm{LK}^{2} \mathrm{PK}\end{array}$ \\
\hline & Kelas 2 & $\begin{array}{l}\mathrm{TDN}=-54,572+6,769 \mathrm{SK}-51,083 \mathrm{LK}+1,851 \mathrm{BETN}-0,334 \mathrm{PK}-0,049 \\
\mathrm{SK} \mathrm{SK}+3,384 \mathrm{LK}^{2}-0,086 \mathrm{SK} \mathrm{BETN}+0,687 \mathrm{LK} \mathrm{BETN}+0,942 \mathrm{LK} \mathrm{PK}- \\
0,112 \mathrm{LK}^{2} \mathrm{PK}\end{array}$ \\
\hline & Kelas 3 & $\begin{array}{l}\mathrm{TDN}=-72,943+4,675 \mathrm{SK}-1,280 \mathrm{LK}+1,611 \mathrm{BETN}+0,497 \mathrm{PK}-0,044 \mathrm{SK} \\
\mathrm{SK}-0,760 \mathrm{LK}^{2}-0,039 \mathrm{SK} \mathrm{BETN}+0,087 \mathrm{LK} \mathrm{BETN}-0,152 \mathrm{LK} \mathrm{PK}+0,074 \\
\mathrm{LK}^{2} \mathrm{PK}\end{array}$ \\
\hline & Kelas 4 & $\begin{array}{l}\mathrm{TDN}=-202,686-1,357 \mathrm{SK}+2,638 \mathrm{LK}+3,003 \mathrm{BETN}+2,347 \mathrm{PK}+0,046 \\
\mathrm{SK} \mathrm{SK}+0,647 \mathrm{LK}^{2}+0,041 \mathrm{SK} \mathrm{BETN}-0,081 \mathrm{LK} \mathrm{BETN}+0,553 \mathrm{LK} \mathrm{PK}- \\
0,046 \mathrm{LK}^{2} \mathrm{PK}\end{array}$ \\
\hline & Kelas 5 & $\begin{array}{l}\mathrm{TDN}=-133,726-0,254 \mathrm{SK}+19,593 \mathrm{LK}+2,784 \mathrm{BETN}+2,315 \mathrm{PK}+0,028 \\
\mathrm{SK} \mathrm{SK}-0,341 \mathrm{LK}^{2}-0,008 \mathrm{SK} \mathrm{BETN}-0,215 \mathrm{LK} \mathrm{BETN}-0,193 \mathrm{LK} \mathrm{PK}+ \\
0,004 \mathrm{LK}^{2} \mathrm{PK}\end{array}$ \\
\hline \multirow[t]{5}{*}{ Wardeh (1981) } & Kelas 1 & $\mathrm{TDN}=-17,2649+1,2120 \mathrm{PK}+0,8352 \mathrm{BETN}+2,4637 \mathrm{LK}+0,4475 \mathrm{SK}$ \\
\hline & Kelas 2 & $\mathrm{TDN}=-21,7656+1,4284 \mathrm{PK}+1,0277 \mathrm{BETN}+0,4867 \mathrm{SK}+1,2321 \mathrm{LK}$ \\
\hline & Kelas 3 & $\mathrm{TDN}=-21,9391+0,4590 \mathrm{SK}+3,0016 \mathrm{LK}+0,9736 \mathrm{BETN}+1,0538 \mathrm{PK}$ \\
\hline & Kelas 4 & $\mathrm{TDN}=40,2625-0,1379 \mathrm{SK}+1,1903 \mathrm{LK}+0,4228 \mathrm{BETN}+0,1969 \mathrm{PK}$ \\
\hline & Kelas 5 & $\mathrm{TDN}=40,3227-0,7007 \mathrm{SK}+1,4218 \mathrm{LK}+0,4448 \mathrm{BETN}+0,5398 \mathrm{PK}$ \\
\hline Moran (2005) & & $\mathrm{TDN}=5,31+0,412 \mathrm{PK}+0,249 \mathrm{SK}+1,444 \mathrm{LK}+0,937 \mathrm{BETN}$ \\
\hline
\end{tabular}


akurasi rumus kecernaan dan partisi energi untuk hijauan pakan tropis di Indonesia. Penelitian ini bertujuan untuk mengetahui hubungan antara Total Digestible Nutrient (TDN) dengan komposisi nutrien hijauan (rumput dan legum) dan untuk menentukan persamaan prediksi TDN menggunakan variabel komposisi nutrien sebagai prediktor yang menunjukkan kualitas hijauan pakan tropis.

\section{MATERI DAN METODE}

\section{Materi Penelitian}

Data dikumpulkan dengan metode desk study menggunakan data sekunder yang diperoleh dari data hasil penelitian dapat berupa tugas akhir mahasiswa di perguruan tinggi yaitu skripsi, tesis dan disertasi dan publikasi ilmiah di terbitan berkala ilmiah baik di terbitan berskala nasional maupun bereputasi internasional yang telah dilakukan dalam kurun waktu 10 tahun terakhir. Data yang digunakan sebanyak 52 hijauan dari 2 referensi dari total 220 hijauan dari 56 refe rensi yang diperoleh. Data yang digunakan adalah data komposisi nutrien dan TDN. Data yang dikoleksi adalah komposisi nutrien hijauan pakan untuk ternak ruminansia meliputi kadar abu, Protein Kasar (PK), lemak kasar (LK), serat kasar (SK), bahan ekstrak tanpa nitrogen (BETN), neutral detergent fiber (NDF), acid detergent fiber (ADF), hemiselulosa, selulosa dan

Tabel 3. Matriks korelasi antara komposisi nutrien dengan TDN

\begin{tabular}{lccc}
\hline \hline \multirow{2}{*}{$\begin{array}{l}\text { Kandungan } \\
\text { Nutrien (\%BK) }\end{array}$} & $\begin{array}{c}\text { Rumput }+ \\
\text { Legum }\end{array}$ & Rumput & Legum \\
\cline { 2 - 4 } Abu & $0,366^{* *}$ & $0,326 * *$ & $0,411^{* *}$ \\
PK & $0,585^{* *}$ & $0,367 * *$ & $0,611^{* *}$ \\
LK & $0,529 * *$ & $0,247 * *$ & $0,496 * *$ \\
SK & $-0,573 * *$ & $-0,245^{* *}$ & $-0,670^{* *}$ \\
BETN & $-0,141 * *$ & $-0,311^{*} *$ & $0,281 * *$ \\
NDF & $-0,510^{* *}$ & $0,008^{* *}$ & $-0,702 * *$ \\
ADF & $-0,382 * *$ & $0,300 * *$ & $-0,622 * *$ \\
Hemiselulosa & $-0,497 * *$ & $-0,312 * *$ & $-0,462 * *$ \\
Selulosa & $-0,401 * *$ & $0,040 * *$ & $-0,521 * *$ \\
\hline *Korelasi nyata (P<0,05);**Korelasi sangat nyata (P<0,01). PK $=$ \\
protein kasar; LK = lemak kasar; SK = serat kasar; BETN = bahan \\
ekstrak tanpa nitrogen; NDF = neutral detergent fiber; ADF = acid \\
detergent fiber; TDN = total digestible nutrient
\end{tabular}

TDN. Data yang dikoleksi dikonversi ke data berbasis $100 \%$ bahan kering (\%BK). Data hijauan pakan akan dibagi menjadi 2 kelompok yaitu hijauan yang termasuk rumput atau graminae $(\mathrm{R}, \mathrm{n}=29)$ dan leguminosa atau kacang-kacangan ( $\mathrm{L}, \mathrm{n}=23$ ). Deskripsi komposisi nutrien dan TDN yang digunakan pada penelitian ini dapat dilihat pada Tabel 1 .

\section{Analisis Data}

Analisis korelasi pearson (Rice, 2007) digunakan untuk mengetahui hubungan komposisi nutrien terhadap TDN, apabila terdapat korelasi nyata akan dilanjutkan dengan mencari persamaan regresi linear berganda (Devore dan Berk, 2012) dengan uji interaksi untuk menentukan model pendugaan. Model dengan probabilitas dan koefisien determinan paling tinggi akan tunjukkan pada hasil. Validasi pada pemodelan dilakukan untuk mengetahui apakah model yang digunakan menggambarkan informasi aktual yang baik dengan membandingkan nilai mean absolute deviation (MAD) ( Tanjung dan Fahmi, 2017), root mean square error (RMSE) (Devore dan Berk, 2012) dan mean absolute percentage error (MAPE) (Mynsbrugge, 2010) dengan model pendugaan TDN Sutardi (1980), Harta di et al. (1980), Wardeh (1981) dan Moran (2005) (Tabel 2). Data diolah menggunakan software Microsoft Excel 2010 dan IBM SPSS versi 22.

\section{HASIL DAN PEMBAHASAN}

\section{Hubungan antara Komposisi Nutrien Hijauan dan TDN}

TDN merupakan sistem asupan energi pada pemberian pakan ternak ruminansia yang digunakan di Indonesia. TDN dapat diketahui dari penjumlahan PK, LK, SK dan BETN yang dapat dicerna. Nilai koefisien korelasi antara komposisi nutrien dengan TDN pada hijauan disajikan pada Tabel 3.

TDN akan meningkat apabila abu, PK dan LK meningkat, sedangkan TDN akan menurun apabila SK dan fraksi serat yaitu NDF, ADF, hemiselulosa dan selulosa meningkat. Berdasarkan hal tersebut PK berkorelasi positif dengan TDN. Jika PK meningkat maka TDN akan meningkat pula. Namun, hanya PK yang berkorelasi dengan TDN rumput disebabkan oleh komposisi nutrien rumput yang beragam. Hijauan dibandingkan dengan konsentrat yang mencerminkan keragaman yang lebih besar dalam kandungan dan

Tabel 4. Model pendugaan TDN

\begin{tabular}{lccccccc}
\hline \multicolumn{1}{c}{ Model } & $\mathrm{n}$ & $\mathrm{R}$ & $\mathrm{R}^{2}$ & $\mathrm{Sig}$ & $\mathrm{MAD}$ & $\mathrm{RMSE}$ & $\mathrm{MAPE}(\%)$ \\
\hline $\mathrm{TDN}_{\mathrm{R}+\mathrm{L}}$ & 52 & 0,660 & 0,436 & 0,000 & 4,45 & 5,67 & 9 \\
$\mathrm{TDN}_{\mathrm{R}}$ & 29 & 0,386 & 0,149 & 0,039 & 4,54 & 5,75 & 10 \\
$\mathrm{TDN}_{\mathrm{L}}$ & 23 & 0,812 & 0,659 & 0,000 & 3,38 & 4,59 & 6 \\
Sutardi (1980) & & & & & 6,04 & 8,04 & 12 \\
Hartadi et al. (1980) & & & & & 7,02 & 9,52 & 14 \\
Wardeh (1981) & & & & 7,34 & 9,24 & 15 \\
Moran (2005) & & & & 10,82 & 13,01 & 22 \\
\hline
\end{tabular}

Keterangan: $\mathrm{MAD}=$ mean absolute deviation $; \mathrm{RMSE}=$ root mean square error , MAPE = mean absolute percentage error 
kecernaan nutrisi di antara hijauan dibandingkan konsentrat karena variasinya yang luas (Owens et al., 2010). PK berkorelasi positif dengan TDN rumput+legum dan legum. Jika PK meningkat maka TDN akan meningkat pula. Selain itu, SK dan fraksi serat yaitu NDF dan ADF berkorelasi kuat $(\mathrm{P}<0,01)$ dengan TDN. SK, NDF dan ADF berkorelasi negatif, jika meningkat maka TDN akan menurun.

PK, LK dan SK memiliki koefisien yang relatif lebih besar terhadap TDN dibandingkan dengan NDF dan ADF. Hal ini disebabkan oleh TDN merupakan sistem energi yang telah dikembangkan berdasarkan kandungan nutrien yang diperoleh dari analisis proksimat yaitu abu, PK, SK, LK dan BETN, tanpa memperhatikan adanya energi yang hilang saat dimetabolis ataupun untuk menghasilkan produk karena terbatasnya peralatan yang tersedia di laboratorium. TDN merupakan gambaran dari total energi yang berasal dari pakan yang dikonsumsi oleh ternak, dimana besar kecilnya nilainya tergantung pada
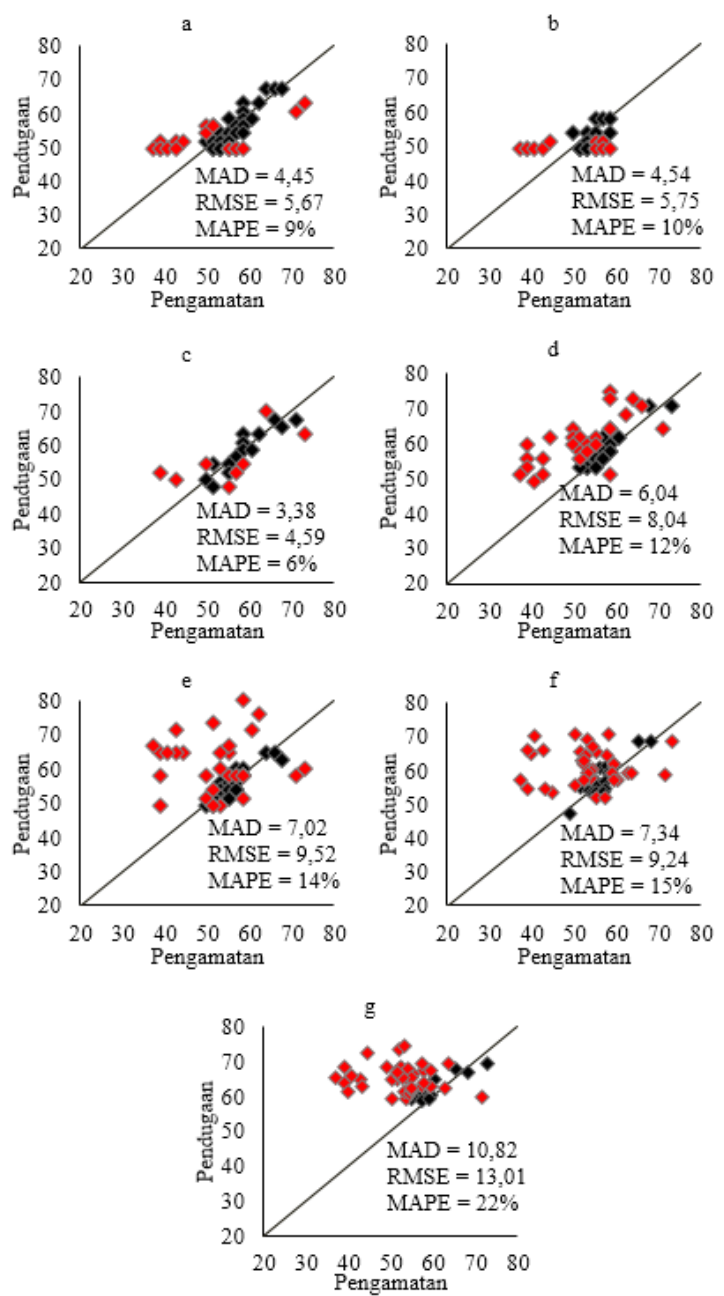

Gambar 1. Hubungan antara TDN dan model pendugaan $\mathrm{TDN}_{\mathrm{R}+\mathrm{L}}$ (a), TDN $\mathrm{R}$ (b), TDN $\mathrm{L}$ (c), Sutardi (1980) (d), Hartadi et al. (1980) (e), Wardeh (1981) (f), Moran (2005) (g) kecernaan bahan organik pakan yaitu PK, SK, LK dan BETN (Mastopan et al., 2014; Nakano et al., 2018).

\section{Model Pendugaan TDN}

Model pendugaan TDN pada hijauan tropis baik untuk rumput dan legum dapat dituliskan sebagai berikut:
$\mathrm{TDN}=49,866-3,488 \mathrm{Abu}+0,112 \mathrm{Abu} * \mathrm{PK}+0,056$
$\ldots\left(\mathrm{TDN}_{\mathrm{R}+\mathrm{L}}\right)$
$\mathrm{TDN}=49,875+0,031 \mathrm{Abu} * \mathrm{PK} \quad \ldots\left(\mathrm{TDN}_{\mathrm{R}}\right)$
$\mathrm{TDN}=15,212+5,084 \mathrm{LK}+0,070 \mathrm{Abu}^{*} \mathrm{BETN} \ldots\left(\mathrm{TDN}_{\mathrm{L}}\right)$

Model pendugaan TDN disajikan pada Tabel 4. Berdasarkan Tabel 4 maka dapat diketahui bahwa model pendugaan TDN yang diperoleh memiliki nilai MAD, RMSE dan MAPE yang lebih kecil bila dibandingkan dengan rumus TDN yang paling sering digunakan yaitu Sutardi (1980), Hartadi et al. (1980), Wardeh (1981) dan Moran (2005). MAD, RMSE dan MAPE merupakan alat validasi penting (De Oca et al., 2017) dalam tahap pemodelan persamaan. Semakin rendah insiden estimasi kesalahan, semakin dekat nilai estimasi dengan nilai yang diamati (Mariano et al., 2013). Validasi kesalahan yang lebih rendah menunjukkan persamaan prediksi dalam penelitian ini dapat digunakan untuk menentukan kualitas TDN untuk hijauan tropis. Model pendugaan TDN pada rumput belum dapat merepresentasikan kualitas hijauan tropis karena memiliki $\mathrm{R}^{2}$ yang rendah bila dibandingkan dengan legum dan rumput+legum yaitu 0,149 atau 14,9\% sehingga masih ada $85,1 \%$. Namun, bukan hanya abu dan PK yang mempengaruhi kualitas $\mathrm{TDN}_{\mathrm{R}}$ karena kandungan nutrien rumput lebih beragam apabila dibandingkan dengan legum. Sehingga untuk menentukan kualitas TDN pada rumput tropis dapat menggunakan $\mathrm{TDN}_{\mathrm{R}+\mathrm{L}}$ yang lebih merepresentasikan TDN pada hijauan tropis.

Terdapat variasi TDN diantara hijauan dibandingkan dengan konsentrat yang mencerminkan keragaman yang lebih besar dalam kandungan dan kecernaan nutrisi di antara hijauan dibandingkan konsentrat karena variasi yang luas pada komposisi nutrien yang ditentukan oleh kadar air, tingkat kematangan dan metode penyimpanan (Owens et al., 2010). Hubungan antara TDN dan model pendugaan TDN disajikan pada Gambar 1. Warna merah pada Gambar 1 menunjukkan under- maupun overestimate yang terdapat pada model pendugaan.

Meskipun demikian diantara keempat rumus TDN tersebut, Sutardi (1980) memiliki nilai MAD, RMSE dan MAPE yang lebih kecil sehingga lebih baik digunakan ketika menduga nilai TDN pada hijauan tropis termasuk di Indonesia. Model persamaan Sutardi (1980) lebih akurat dalam menduga TDN tercerna setelah dibandingkan dengan kecernaan TDN menurut Wardeh (1981) dan Hartadi et al. (2005). Hal tersebut terlihat setelah menguji berbagai jenis ransum dengan TDN dan protein berbeda pada domba (Hernaman et al., 2018). 
Jayanegara et al. (2019) telah mengestimasi dan memvalidasi penentuan model TDN berdasarkan kualitas pakan pada konsentrat dan hijauan untuk digunakan dalam penentuan TDN pada pakan komplit. Namun, penentuan model TDN hanya pada umumnya hijauan, tidak dijabarkan pada kualitas rumput dan legum. Sebelumnya, Owens et al. (2010) menentukan model TDN pakan dengan berdasarkan jenis hijauan. Akan tetapi, komposisi nutrien berdasarkan tabel National Research Council (NRC) yang bukan kualitas tropis.

\section{KESIMPULAN}

Model pendugaan TDN secara akurat dapat diestimasi dari komposisi nutrien sehingga dapat digunakan untuk merepresentasikan TDN berdasarkan basis data hijauan tropis. Model pendugaan TDN yaitu $\mathrm{TDN}_{\mathrm{R}+\mathrm{L}}=49,866-3,488 \mathrm{Abu}+0,112 \mathrm{Abu} * \mathrm{PK}+$ $0,056 \mathrm{Abu}^{*} \mathrm{BETN}$ dan $\mathrm{TDN}_{\mathrm{L}}=15,212+5,084 \mathrm{LK}+$ 0,070 Abu*BETN. TDN $\mathrm{A}_{\mathrm{R}}$ kurang akurat digunakan dalam merepresentasikan TDN pada rumput karena variasi kualitas yang sangat luas sehingga tidak dapat digunakan.

\section{DAFTAR PUSTAKA}

Archimede, H., M. Rira, M. Eugene, J. Fleury, M.L. Lastel, F. Periacarpin, T. Silou-Morgavi and M. Doreau. 2018. Intake, total-tract digestibility and methane emissions of texel and blackbelly sheep fed c4 and c3 grasses tested simultaneously in a temperate and a tropical area. Journal of Cleaner Production 185: 455-463.

Cleland, J.D., E. Johnson, P.C.H. Morel, P.R. Kenyon and M.R. Waterland. 2018. Mid-infrared reflectance spectroscopy as a tool for forage feed composition prediction. Animal Feed Science and Technology 241: 102-111.

Detmann, E., V.S.C. Filho, D.S. Pina, L.T. Henriques, M.F. Paulino, K.A. Magalhaes, P.A. Silva and M.L. Chizzoti. 2008. Prediction of the energy value of cattle diets based on the chemical composition of the feeds under tropical conditions. Animal Feed Science and Technology 143: 127-147.

De Oca, M.R.M.M., Ferreira, L.G., Lima, R.R., Goncalves, T.M., Saad F.M.O.B., Zangeronimo MG. 2017. Prediction equations for metabolizable and digestible energy in feline diets. Animal Feed Science and Technology 228: 91-101.

Devore, J.L. and K.N. Berk. 2012. Modern Mathematical Statistics with Applications. 2nd Ed. Springer Texts in Statistics. New York, United State of America.

Farizaldi. 2011. Produktivitas hijauan makanan ternak pada lahan perkebunan kelapa sawit berbagai kelompok umur I PTPN 6 Kabupaten Batanghari Provinsi Jambi. Jurnal Ilmiah Ilmu-Ilmu Peternakan 14(2): 68-73.
Ferrel, C.L. and J.W. Oltjen. 2008. Asas centennial paper: net energy systems for beef cattle-concepts, aplication and future models. Journal of Animal Science 86:2779-2794.

Ginting, S.P. 2011. Teknologi peningkatan daya dukung pakan di kawasan hortikultura untuk ternak kambing. Wartazoa 21(3): 99-107.

Hartadi, H., S. Reksohadiprojo, S. Lebdosukojo dan A.D. Tillman. 1980. Tabel-Tabel Komposisi Bahan Makanan Ternak untuk Indonesia. International Feedstuffs Institute Utah Agricultural Experiment Station, Utah State University. Logan, United State of America.

Hernaman, I., B. Ayuningsih dan D. Ramdani. 2018. Perbandingan model pendugaan total digestible nutrient (tdn) dan protein tercerna pada domba garut betina. Majalah Ilmiah Peternakan 21(3): 110-113.

Jayanegara, A., M. Ridla, D.A. Astuti, K.G. Wiryawan, E.B. Laconi and Nahrowi. 2017. Determination of energy and protein requirements of sheep in Indonesia using a meta-analytical approach. Media Peternakan 40(2): 118-127.

Jayanegara, A., M. Ridla, Nahrowi, E.B. Laconi. 2019 Estimation and validation of total digestible nutrient values of forage and concentrate feedstuffs. IOP Conference Series: Materials Science and Engineering 546: 042016.

Koten, B.B., R. Wea, R.D. Soetrisno, N. Ngadiyono dan B. Soewignyo. 2014. Konsumsi nutrien ternak kambing yang mendapatkan hijauan hasil tumpangsari arbila (Phaseolus lumatus) dengan sorgum sebagai tanaman sela pada jarak tanam arbila dan jumlah baris sorgum yang berbeda. Jurnal Ilmu Ternak 1(8): 38-45.

Mastopan, M. Tafsin dan N.D. Hanafi. 2014. Kecernaan lemak kasar dan tdn (total digestible nutrient) ransum yang mengandung pelepah daun kelapa sawit dengan perlakuan fisik, kimia, biologis dan kombinasinya pada domba. Jurnal Peternakan Integratif 3(1): 37-45.

Mariano, F.C.M.Q., C.A. Paixao, R.R. Lima, R.R. Alvarenga, P.B. Rodrigues, G.A.J. Nascimento. 2013. Prediction of the energy values of feedstuffs for broilers using meta-analysis and neural networks. Animal 7(09): 1440-1445.

Mynsbrugge, J.V. 2010. Bidding Strategies Using Price Based Unit Commitment in a Deregulated Power Market. Tesis. Katholieke Universiteit Leuven. Leuven, Belgia.

Moran, J. 2005. Tropical Dairy Farming: Feeding Management for Small Holder Daiy Farmers in the Humid Tropics. Landlinks Press Collingwood, Australia.

Nakano, H., K. Matoba, Y. Togamura. 2018. An estimation for total digestible nutrient in fresh herbage from a perennial ryegrass - white clover mixed pasture. JARQ 52(2): 155-161.

Nugroho, D., A. Purnomoadi dan E. Riyanto. 2013. Pengaruh imbangan protein kasar dan total 
digestible nutrients pada pakan yang berbeda terhadap pemanfaatan energi pakan pada domba lokal. Sains Peternakan 11: 63-69.

Owens, F.N., D.A. Sapienza and A.T. Hassen. 2010. Impat of nutrient composition of feeds on digestibility of organic matter by cattle: a review. Journal of Animal Science 88(12 Suppl): E15169.

Rice, J.A. 2007. Mathematical Statistics and Data Analysis. Thomson Brooks, Cole. Belmont, United State of America.

Rosendo, O., L. Freitez and R. Lopez. 2013. Ruminal degradability and summative models evaluation for total digestible nutrients prediction of some forages and byproducts in ghoats. ISRN Veterinary Science 1-8.
Seglar, W.J. and R.D. Shaver. 2014. Management and assessment of ensiled forages and high moisture grain. Veterinary Clinics of North America: Food Animal Practice 30(3): 507-538.

Sutardi, T. 1980. Landasan Ilmu Nutrisi. Departemen Ilmu dan Makanan Ternak Fakultas Peternakan. Institut Pertanian Bogor. Bogor.

Tanjung, L.M. dan A. Fahmi. 2017. Perhitungan peramalam pengadaan obat menggunakan metode single exponential smoothing dan single moving average pada Unit Farmamin Dinas Kesehatan Provinsi Jawa Tengah. Journal of Information System 2(2): 234-243.

Wardeh, M.F. 1981. Model for Estimating Energy and Protein Utilization for Feeds. Disertasi. Utah State University. Utah, United State of America. 